D.E.L.T.A., Vol. 16, N. 1, 2000 (1-26)

\title{
Uma Experiência de Assessoria Docente e de ElaboraÇão de Material Didático para o Ensino de Produção DE Textos na Universidade ${ }^{1}$ \\ (An experience in advice for teaching and materials preparation for the teaching of writing at a university)
}

\author{
Anna Rachel MACHADO \\ (Pontifícia Universidade Católica de São Paulo)
}

\begin{abstract}
..."il y a dans l'esprit du temps ou dans la vie de chacun d'entre nous des moments de tolérance, de reconnaissance de la multiplicité des points de vue, et d'autres moments où un point de vue s'impose, met les autres à l'arrièreplan, que ce soit dans l'urgence de l'indignation, de la révolte, de l'élan amoureux ou de la croyance. Enfin, qu'il subsiste toujours une distance entre le point de vue dit et la pratique 'réelle', par exemple perçue par l'autre.

F. François, Morale et Mise en Mots.
\end{abstract}

ABSTRACT: Based on social interactionism, this article aims to report and analyse part of a university advisory job on instructions for textual production at academic levels, in which consultants and teachers focused on the elaboration of didactic material for university students, more specifically, the production of a didactic sequence for a genre, the 'critical review article'. The different steps and analyses carried out to put the project forward are discussed together with the theoretical and interactional problems that had to be faced, so as to finally raise the conclusions about the consulting job itself and the suggested procedures for the design of the didactic material.

KEY WORDS: didatic transposition, socio-discoursive interacionisme, genre, didactic sequence, opinion article.

\footnotetext{
${ }^{1}$ Nossos agradecimentos: à FAEP - Fundação de Amparo ao Ensino e Pesquisa, da Universidade de Mogi das Cruzes, pelo subaídio à assessoria docente aqui discutida; ao Instituto de Assessoria e Pesquisa em Linguagem Litteris, responsável pelo projeto mais amplo a que essa assessoria docente se vincula; à Prof ${ }^{a}$. Dr. ${ }^{a}$. Maria Cecília Camargo Magalhães, pela valiosa participação em todas as fases de trabalho desenvolvido junto aos professores; finalmente, aos professores da Universidade de Mogi das Cruzes: Elaine Baltasar de Araújo Montanhez, Eliana de Azevedo Arouca, Elizabeth Eboli de Mello, Elza Maria Tavares Silva, Luci M. Melo Bonini, Márcia de Azevedo Arouca, Sérsi Bardari, Vera Lúcia Meira Magalhães e William Araújo, que continuamente me fizeram repensar, rever e reelaborar minhas certezas.
} 
ResUMo: Este artigo tem o objetivo de relatar e analisar, com base no interacionismo sócio-discursivo, parte de uma experiência de assessoria docente voltado para o ensino de produção de textos na universidade, em que assessores e professores se concentraram na elaboração de material didático apropriado para esse nível de ensino; mais especificamente, na construção de uma seqüência didática dirigida para o ensino da produção de textos pertencentes ao gênero artigo de opinião. Nele são apresentadas as diferentes etapas e análises realizadas para esse trabalho, os problemas teóricos e interacionais enfrentados, assim como as respectivas soluções, para, enfim, chegarmos a conclusões sobre o trabalho de assessoria e sobre os procedimentos utilizados para a elaboração do referido material didático. PALAVRAS-CHAVE: transposição didática, gênero, seqüência didática, interacionismo sócio-discursivo artigo de opinião.

\section{Introdução}

Este artigo centra-se no relato e na análise de parte de uma experiência de assessoria docente voltada para a implementação de modificações no ensino de produção de textos na universidade, na qual elaboramos material didático pertinente para alunos universitários do primeiro ano das áreas pertencentes às Ciências Humanas, como uma das atividades previstas em um projeto mais amplo de intervenção didática, o Projeto Cultura da Escrita: atividades de leitura e de produção de textos na universidade (Rangel et allii., 1998).

Trata-se aqui, portanto, também de uma experiência de transposição didática, na qual dois assessores docentes, junto a nove professores universitários, partiram de um conjunto de conhecimentos científicos e práticos para a construção de uma sequiência didática (ou módulo didático, segundo os Parâmetros Curriculares Nacionais para Língua Portuguesa (cf. Bräkling et allii., 1998: 80) voltada para o ensino-aprendizagem de um gênero específico, o artigo de opinião. A transposição didática é por nós compreendida como o conjunto das transformações que um determinado corpo de conhecimentos científicos invariavelmente sofre, com o objetivo de ser ensinado, implicando, necessariamente, determinados deslocamentos, rupturas e transformações diversas nesse conjunto de conhecimentos, e não como uma mera aplicação de uma teoria de referência qualquer. No nosso caso específico, os conhecimentos científicos de que nos servimos provieram, basicamente, como se verá na próxima seção, do chamado interacionismo sócio-discursivo. 
Nossa hipótese central, nesse trabalho, era a de que a elaboração do material didático deveria ter a participação efetiva dos professores da universidade, uma vez que essa participação poderia lhes dar o estatuto de agentes responsáveis por todo o processo e lhes forneceria uma possibilidade efetiva de transformação/refinamento de seus saberes e de suas práticas didáticas.

Assim, mantínhamos a hipótese de que a situação de comunicação criada nesse trabalho de assessoria se constituía como um verdadeiro sistema triádico (tal como é concebido o próprio sistema didático), formado por três pólos: os assessores, os professores e determinados objetos de conhecimento. Analogamente ao que se pensa sobre o sistema didático, a atividade social que se desenvolveria nas sessões de assessoria deveria ser mediada pela construção conjunta de conhecimentos, na qual o estudo dos gêneros e a elaboração do material didático se constituiriam como instrumentos privilegiados, no sentido vigotskiano do termo.

Dada a multiplicidade de questões envolvidas no trabalho desenvolvido, vários são os objetivos deste artigo. Em primeiro lugar, fornecer um exemplo concreto de como se pode efetivar uma transposição didática para o ensino de produção de textos centrada na noção de gêneros de textos, apresentando suas diferentes fases, os problemas que foram se colocando e as soluções que foram sendo encontradas. Em seguida, apresentar e analisar os principais conflitos vivenciados na interação com os professores e as negociações que se fizeram necessárias para superá-los, inclusive na discussão que com ele mantivemos a respeito da primeira versão deste artigo. Enfim, apresentar uma avaliação geral sobre essa experiência, com as conclusões a que podemos chegar até o momento e com novas hipóteses e considerações de ordem teórica e metodológica referentes aos procedimentos de elaboração do material didático, ao desenvolvimento de conhecimentos dos professores e ao trabalho de assessoria.

\section{Pressupostos teóricos: O interacionismo sócio-discursivo, a transposição e a seqüiência didática}

Os pressupostos teóricos de todo o trabalho desenvolvido serão expostos em três grandes blocos: no primeiro, os conceitos mais gerais sobre a produção de linguagem e a aprendizagem; no segundo, princí- 
pios sobre transposição didática e, finalmente, as orientações referentes à construção de sequiências didáticas.

A base teórica geral concentra-se no interacionismo sóciodiscursivo, proposto pelos pesquisadores de Genebra, explicitado em Bronckart (1997) e baseado em três grandes autores: Vigotski, Bakhtin e Habermas. De acordo com esse interacionismo, na ontogênese humana, as atividades e as produções de linguagem do ambiente social desempenham um papel central, pois são elas que levam o desenvolvimento humano na direção de um pensamento consciente. No quadro dessas atividades sociais de linguagem e no quadro de uma formação social, desenvolvem-se as ações de linguagem [action langagière, no original] dos indivíduos particulares.

A ação de linguagem é definida por Bronckart (1997:101-102), em dois níveis: "no primeiro nível, sociológico, como uma porção da atividade de linguagem do grupo, recortada pelo mecanismo geral das avaliações sociais e imputada a um organismo humano singular (...) e num segundo nível, psicológico, como o conhecimento, disponível no organismo ativo, das diferentes facetas da sua própria responsabilidade na intervenção verbal". É nesse segundo nível que o tomamos, conforme o próprio autor, e nesse nível, "a noção de ação de linguagem federa e integra (...) as representações dos parâmetros do contexto de produção e do conteúdo temático, tais como um agente determinado as mobiliza quando realiza uma intervenção verbal". Tais ações estão inexoravelmente ligadas à utilização das formas comunicativas que se encontram em uso numa determinada formação social, isto é, à utilização dos gêneros de texto.

Essa utilização, entretanto, não é uma simples cópia desses modelos, mas envolve uma dialética entre as representações do agente produtor sobre sua situação de ação e seus conhecimentos sobre os gêneros de textos e sobre a língua de uma determinada sociedade. $O$ produto final desse processo é um texto ${ }^{2}$, unidade comunicativa de nível superior, que apresenta tanto características comuns ao gênero ao qual se filia, quanto características singulares, traços das decisões tomadas pelo produtor, em função de suas representações sobre a situação em que se encontra.

\footnotetext{
${ }^{2}$ A noção de texto, nessa teoria, não pode ser confundida com a noção de texto visto como uma estrutura sem relação com o contexto. Nessa teoria, as relações com o contexto e com o intertexto estão sempre presentes, nos diferentes níveis da análise.
} 
A noção de gênero de texto, para Bronckart, é equivalente à noção bakhtiniana (cf. Bakhtin,1953:279) de gênero do discurso, segundo a qual as diferentes esferas das atividades humanas, sócio-historicamente, elaboram tipos relativamente estáveis de enunciados, os gêneros de discurso, que se caracterizam por apresentarem conteúdos, estruturação, relações entre os interlocutores e estilo específicos.

Em artigo dos mais importantes para a compreensão do papel dos gêneros no uso da linguagem, Schneuwly (1994) mobiliza essa noção, reconceitualizando-a no quadro da psicologia vigostkiana, fornecendo-nos uma das concepções mais vigorosas para a questão do ensinoaprendizagem de produção e leitura e para a elaboração de materiais didáticos adequados. Em primeiro lugar, o autor (cf. Schneuwly, 1994:157) nos relembra que, no quadro da epistemologia marxista, a atividade humana em geral é concebida como tripolar, envolvendo um sujeito (primeiro pólo) que age sobre objetos ou situações (segundo pólo), utilizando objetos específicos, socialmente elaborados (terceiro pólo). Estes são ferramentas ou instrumentos para a ação, que determinariam o comportamento do indivíduo, guiando, aperfeiçoando e diferenciando sua percepção da situação em que se encontra.

Analogamente, Schnewly (cf. 1994:160-162) considera que, nas atividades de linguagem, os gêneros se constituem como verdadeiras ferramentas semióticas complexas que permitem a produção e a compreensão de textos. A participação dos agentes em diferentes atividades sociais possibilita que construam, no decorrer de suas vidas, tanto os conhecimentos sobre os gêneros em uso em sua sociedade quanto os esquemas necessários para sua utilização, que permitem que os gêneros sejam adaptados a diferentes situações concretas e que orientam as diferentes operações necessárias à produção textual.

Quanto à segunda noção sobre a qual é necessário também nos determos, a situação de ação de linguagem, ela é caracterizada por Bronckart (cf. 1997:94) como um conjunto de versões particulares do agente de determinadas representações sociais sobre o mundo físico e o mundo sócio-subjetivo. São, portanto, representações interiorizadas pelos agentes, que são mobilizadas pelo agente diante da necessidade de produção de linguagem e que exercem influência decisiva sobre vários aspectos do texto produzido. Nesse processo, elas são mobilizadas em duas direções: um conjunto de representações constituirá o contexto da produção e outras representações constituirão o conteúdo 
temático ou referente. O contexto de produção é caracterizado (cf. Bronckart, 1997:95-100) pelos seguintes parâmetros: o local e o momento da produção, o emissor e o receptor considerados do ponto de vista físico; a instituição social onde se dá a interação, os papéis sociais representados pelo emissor (enunciador) e pelo receptor (destinatário), e o(s) objetivo(s) que o produtor quer atingir com sua produção de linguagem.

Em relação aos procedimentos de transposição didática, Bronckart (cf. 1993:7) assinala que a análise da atividade educacional deve constituir-se como um passo inicial, devendo essa análise incidir sobre os três níveis constitutivos dessa atividade. O primeiro desses níveis é o do sistema educacional, isto é, do conjunto de instruções oficiais e de textos que expressam as expectativas da sociedade em relação às questões educacionais ou que buscam propor um plano geral de ações que, idealmente, conduziriam os alunos a se tornarem membros efetivos dessa sociedade. O segundo nível seria o dos sistemas de ensino, isto é, o das instituições escolares de uma sociedade, que se diferenciam em função da idade, do nível cognitivo suposto e do estatuto sócio-econômico dos alunos e que também produzem discursos sobre objetivos, programas, conteúdos e métodos de ensino, que acabam dando forma às intervenções didáticas. Finalmente, o terceiro nível é o dos sistemas didáticos (ou triângulos didáticos), estruturas particulares constituídas pelo professor, pelos alunos, pelos objetos de conhecimento (ou conteúdos) e pelas relações entre esses três elementos, entre os quais há uma interdependência radical, de tal forma que "qualquer intervenção sobre um ou outro dos termos desse sistema traz necessariamente conseqüências diretas para os outros elementos" (cf. Bronckart \& Schneuwly: 1991:16).

Considerados esses três níveis da atividade educacional, torna-se necessário observarmos princípios mais específicos da transposição didática referentes ao ensino-aprendizagem de produção de textos. Em primeiro lugar, tomando a apropriação, pelos aprendizes, das diferentes dimensões constitutivas dos mais variados gêneros de texto como objetivo unificador de diferentes atividades de ensino que possam constituir uma unidade, o grupo de Genebra propõe que as práticas escolares sejam norteadas pelos chamados modelos didáticos dos gêneros a serem apropriados.

De Pietro et allii (cf. 1997:108) definem o modelo didático como sendo "um objeto descritivo e operacional, construído para apreender o fenômeno complexo da aprendizagem de um gênero e, assim, orien- 
tar suas práticas", que desempenha um papel de exemplo do gênero em questão. Ainda segundo esses autores, sendo orientada por objetivos didáticos, a construção desse modelo não precisa ser perfeita nem teoricamente pura, podendo reunir referências teóricas diversas, assim como referências oriundas da observação e da análise das práticas sociais que envolvem o gênero em questão e dos depoimentos dos "experts" na sua produção. Finalmente, as próprias atividades das aulas que se centrarem nesse gênero possibilitariam um retorno ao modelo didático, permitindo a sua reelaboração contínua.

Assim, chegamos ao ponto mais específico do processo de transposição didática para o ensino de produção de textos, que é o da seqüência didática. Embora utilizemos a noção de seqüência didática tal como estabelecida por Schneuwly (1991) e por Dolz e Schneuwly (no prelo), conforme veremos a seguir, ela é concebida de forma mais ampla por Masseron (1996:4), que a define como "uma sequiência de atividades progressivas, planificadas, dirigidas por um tema, um objetivo geral ou por uma produção". Do mesmo modo, embora essa noção e os conceitos didáticos relacionados a ela tenham sido divulgados entre nós só a partir da divulgação dos trabalhos do dois autores acima citados; segundo Masseron (cf. 1996:3), ela já aparecia em Pratiques, 53 (1988) sob o conceito de ciclo de aprendizagem, com o qual já se evidenciava a preocupação em integrar a problemática das aquisições em escrita em um quadro de ensino homogêneo.

Para Schneuwly (cf. 1991:134-137) e Dolz \& Schneuwly (cf:. no prelo:3-6), a seqüência didática se define como a unidade de trabalho escolar, constituída por um conjunto de atividades que apresentam um número limitado e preciso de objetivos e que são organizadas no quadro de um projeto de apropriação de dimensões constitutivas de um gênero de texto, com o objetivo de estruturar as atividades particulares em uma atividade englobante, de tal forma que essas atividades tenham um sentido para os aprendizes.

A estrutura dessas seqüências é constituída por três etapas interrelacionadas. Na primeira, há uma primeira produção de textos, pelos alunos, no quadro de um projeto de classe, para serem avaliadas as suas capacidades iniciais e serem identificados os problemas. Na segunda, são desenvolvidos ateliers, nos quais os alunos realizam diferentes atividades e exercícios direcionados para o projeto de apropriação das características fundamentais do gênero estudado. Finalmente, 
na terceira, há uma produção final, em que os alunos avaliam e revisam suas produções iniciais, guiados por uma ficha de controle, construída individual e/ou coletivamente durante os ateliers. Dessa forma, os alunos podem colocar em prática, de forma global, os conhecimentos e os procedimentos aprendidos, em função dos objetivos e das atividades realizadas.

Finalizada a exposição dos pressupostos teóricos básicos do trabalho que desenvolvemos, passemos, a seguir, à sua primeira fase, que consistiu em um levantamento das características dos três níveis da atividade educacional que se constituía como o contexto mais amplo desse trabalho.

\section{Os três níveis da atividade educacional envolvida}

Nessa primeira fase, buscamos identificar e conceitualizar os problemas existentes na situação específica em que se realizaria o trabalho, analisando as condições concretas da intervenção. Para esse levantamento inicial, foram utilizados documentos relativos à política educacional brasileira, especificamente a universitária; as questões do Exame Nacional de Cursos $^{3}$, de 1997 e 1998, que exigem produção de textos e a própria demanda feita pela universidade.

Em primeiro lugar, no nível do sistema educacional, verificamos que o atual Ministério da Educação propõe-se a realizar profundas transformações no ensino em geral, e no universitário em particular, tomando medidas concretas para que essas modificações ocorram. Assim, a introdução desses exames é divulgada pelo Ministério, não como uma avaliação individual dos alunos, mas como forma de avaliar a qualidade de ensino das universidades, termo esse dos mais freqüientes nos discursos oficiais.

Para compreender, pelo menos parcialmente, em relação à produção de textos, o que se considera como qualidade e o que se espera do aluno egresso das universidades, foram analisadas as instruções dos exames destinados a alunos de Administração, Odontologia, Direito, Letras, Jornalismo, Engenharia Civil, Engenharia Química, Veteriná-

3 Esse exame é feito pelo Ministério da Educação do Brasil e dirigido a recém-egressos de diferentes cursos universitários, como parte da avaliação da qualidade de ensino das universidades brasileiras. 
ria. Tendo em mãos apenas as questões da prova, foi necessário que desenvolvêssemos um trabalho de formulação de hipóteses a respeito dos textos ideais que se pretendia que os alunos produzissem a partir dessas questões.

Tomando o modelo de análise proposto por Bronckart (1997), foram levantadas as diferentes características textuais que deveriam estar presentes nesses textos. O que pudemos concluir é que, de forma geral, os jovens submetidos a esses exames, para que pudessem ser bem sucedidos, deveriam saber realizar, de forma adequada, diferentes operações de linguagem, tais como:

- mobilizar representações adequadas à própria situação do referido exame, assim como ficcionalizar situações em que agiriam com a linguagem como profissionais de sua área;

- compreender o que realmente significam inúmeros atos de linguagem, que são colocados de forma mais ou menos vaga pelos avaliadores, tais como "comente", "explique", "responda";

- utilizar mecanismos linguíístico-discursivos específicos de diferentes gêneros de textos apropriados a cada área, como por exemplo, planejamento de pauta, pareceres, diagnósticos, planos de tratamento;

- construir diferentes tipos de discurso e/ou de organização textual, como descrever, argumentar, justificar, fundamentar, exemplificar, enumerar, relatar, definir, comparar, etc.

Assim, o domínio dessas operações de linguagem parece ser considerado como um dos sinais da qualidade esperada pelo sistema educacional. Essas conclusões, assim, constituíram-se como critérios importantes - embora, de forma alguma, exclusivos - na operacionalização da sequiência didática que foi construída.

Em segundo lugar, tomemos o segundo nível da atividade educacional, o do sistema de ensino envolvido; no caso, a própria universidade envolvida. Nela, uma universidade particular do Estado de São Paulo, pudemos verificar que o movimento observado no nível do sistema educacional brasileiro refletia-se claramente em um discurso que também privilegiava a questão da qualidade do ensino. Profundas e rápidas modificações estavam naquele momento sendo introduzidas no sistema de ensino por novos núcleos de poder, dirigidos por profissionais recém-contratados, que eram considerados como sendo de alto nível acadêmico e administrativo. 
Já em relação à análise do terceiro nível da atividade educacional, o dos sistemas didáticos envolvidos, ela não pôde apoiar-se em métodos de coleta de dados mais formalizados, mas foram e estão sendo construídas nas próprias discussões com os professores. Assim, em relação a estes, verificamos que apresentam uma experiência docente largamente suficiente e uma boa formação acadêmica, encontrando-se a grande maioria em estudos de mestrado ou doutorado. Essa formação é bastante diversificada, desenvolvendo-se ela em várias áreas, como a Semiótica, a Lingüística Aplicada, a Comunicação Social e a Educação.

Em relação ao corpo discente, a maior parte é constituída por jovens que trabalham o dia inteiro, moradores da periferia da cidade de São Paulo e que, à noite, se locomovem até a cidade onde está a universidade para fazerem seus estudos. De modo geral, apresentavam pouca base para os estudos universitários, além de terem pouco tempo para tarefas escolares ou para leituras extras.

Em relação aos conhecimentos efetivamente ensinados em sala de aula, constatamos que, havia uma certa dificuldade em relação às transposições didáticas dos conhecimentos científicos já assimilados pelos professores para as práticas de ensino. Assim, a melhoria do ensino de produção de textos nos parecia ser dependente da definição, seleção e transposição didática adequadas de objetos de conhecimento que realmente pudessem levar ao desenvolvimento das capacidades lingüísticodiscursivas necessárias para a produção de textos.

Portanto, admitida a interdependência entre os três pólos do triângulo didático, passamos a considerar que, com a intervenção dirigida para um desses vértices, os objetos de conhecimentos, poderíamos efetuar reais transformações nos pólos dos sistemas didáticos envolvidos. E foi esse o desafio que buscamos enfrentar, da forma relatada a seguir.

\section{A construção da seqüência didática no quadro da assessoria docente}

Esta seção está dividida em três itens maiores: o relato de como se buscou a construção inicial de um corpo de conhecimentos comuns aos participantes do processo, o relato das várias etapas e análises cumpridas para a construção da seqüência didática, com todos os seus problemas e soluções, e, finalmente, a apresentação das características gerais dessa seqüência. 
A construção inicial de um corpo de conhecimentos comuns

Iniciando esse trabalho de assessoria, na primeira etapa, no final do primeiro semestre de 1998 , foram realizados encontros semanais com os professores (de 12 a 8 professores, sendo o último número o mais constante), num total de 24 horas. A meta central era a construção de um corpo de conhecimentos comuns a todos os participantes, efetivada com a apresentação do trabalho que cada professor já realizava em suas aulas e com discussões teóricas de artigos que já relacionam a teoria com a transposição didática (Dolz e Pasquier, 1993; Pasquier e Dolz, 1996; e de Pietro et allii, 1997). Ao final dessa etapa, foi delineado o planejamento do trabalho para o segundo semestre, que incluía, não só um projeto-piloto com a utilização de uma seqüência didática, mas também a elaboração de seqüências didáticas específicas para diferentes cursos, a serem utilizadas em 1999.

\section{A construção da seqüência didática}

Em agosto e setembro de 1998, os encontros, num total de 24 horas, voltaram-se para a construção da sequiência destinada ao projeto-piloto. No decorrer da semana, sugestões para a sequiência foram sendo elaboradas por nós, sendo elas posteriormente discutidas e apresentadas aos professores para esclarecimento, crítica, discussão e reelaboração posterior. Todo esse processo foi desenvolvido conforme descrito a seguir.

Em primeiro lugar, buscou-se estabelecer um objetivo global para o conjunto da seqüência. Considerando que grande parte das questões do Exame Nacional de Cursos e das atividades escolares, assim como necessidades sociais mais amplas, exigem que o aluno se posicione sobre uma determinada questão e que a justifique, o objetivo de "desenvolver algumas das capacidades envolvidas na produção de um gênero com características argumentativas" foi escolhido, dando-se ênfase especial à operação de justificação.

Entretanto, esse objetivo ainda era muito vago, pois vários gêneros poderiam ser explorados para alcançá-lo. Qual desses gêneros escolher? 
Para essa escolha, levamos em conta três critérios:

a) que o gênero escolhido atendesse as necessidades dos alunos em situações escolares ou extra-escolares habituais, nas quais eles se defrontam com uma situação de ação de linguagem em que devem se posicionar e argumentar diante de um tema e de uma questão previamente dada por um terceiro;

b) que o gênero escolhido não fosse totalmente novo para eles, isto é, que não estivesse muito distante dos conhecimentos dos alunos e dos professores;

c) que, para a produção de textos pertencentes a esse gênero, houvesse restrições situacionais, temáticas e composicionais claras, que pudessem ser trabalhadas em aula.

De acordo com esses critérios, escolhemos o gênero artigo de opinião de jornal, de um tipo específico, ao qual se filiam os artigos da seção Tendências e Debates do jornal Folha de S. Paulo, da edição dos sábados, que atendia esses critérios. Chegamos, assim, à definição do projeto global da sequiência, isto é, o de levar os alunos a se apropriarem desse gênero, desenvolvendo as capacidades implicadas na produção de textos a ele pertencentes.

A seguir, começamos o trabalho da caracterização das dimensões constitutivas desse gênero, que seriam objeto prioritário das atividades em aula, que, segundo nossos pressupostos teóricos correspondem às capacidades $^{4}$ que devem ser desenvolvidas no trabalho didático. Para isso, nosso trabalho consistiu em:

a) em primeiro lugar, definir a situação de ação de linguagem em que esses textos são produzidos;

b) em segundo lugar, efetuar análises de textos pertencentes a esse gênero, de acordo com o modelo de análise exposto em Bronckart (1997).

\footnotetext{
${ }^{4}$ Segundo Dolz \& Schneuwly (1998:76-81), três grandes tipos de capacidades estão envolvidas: as capacidades de ação, que envolvem três tipos de representações (do meio físico, da interação comunicativa, dos conhecimentos de mundo mobilizados como conteúdos), as capacidades discursivas (a gestão da infraestrutura geral do texto e a escolha e elaboração de conteúdos), as capacidades lingüístico-discursivas, que envolvem quatro tipos de operações: de textualização, de atribuição de responsabilidade enunciativa (prise en charge énonciative), de construção de enunciados e de escolha de itens lexicais. Como se vê, essas capacidades correspondem aproximadamente aos níveis de constituição dos textos propostos por Bronckart (1996).
} 
Em primeiro lugar, podemos dizer que a situação de ação de linguagem correspondente aos textos pertencentes ao gênero artigo de opinião específico com que trabalhamos é uma situação específica de produção - uma situação de argumentação explícita (cf. Dolz \& Pasquier, 1993). Nessa situação, o produtor deve responder, em seu texto, a uma questão controversa que lhe é colocada pelo próprio jornal. Essa questão é colocada em evidência na página do jornal no qual o texto se encontra, abordando um tema atual, de ordem social, política, econômica ou cultural. Evidentemente, são os editores do jornal que determinam que a questão é discutível, isto é, que não há consenso sobre ela na sociedade, assim como a sua relevância para os leitores. Dessa forma, os conhecimentos de mundo que os produtores devem mobilizar são parcialmente condicionados por essa questão.

Em relação à representação de si mesmos que esses produtores devem mobilizar para a produção, em primeiro lugar, é preciso observar que eles são convidados pelo jornal para produzi-los, como representantes de uma determinada instituição social afetada pela questão ou que a quem se atribui autoridade para se manifestar sobre ela: o governo, os sindicatos, a academia, o judiciário, a empresa, etc. Assim, é essa sua representação desse papel social que o produtor deve mobilizar ao produzir o texto, o que pode ser claramente visto pela aposição à sua assinatura da função que exerce nessas instituições.

Além disso, o conhecimento que esses produtores tem sobre esse jornal e sobre essa seção específica, na qual se encontram dois ou três textos com posições diferentes sobre a questão colocada, torna-o consciente de que outra pessoa, com uma função social determinada também foi convidada para defender uma posição diferente da sua, o que reforça sua representação da situação como situação de argumentação, que, embora implique uma produção monologal, é explicitamente dialógica.

As representações sobre os destinatários desses artigos é a de que são os leitores mais ou menos fiéis desse jornal, especialistas sobre a questão proposta ou nela interessados, ou ainda leitores que buscam seguir os acontecimentos e os debates da atualidade, e que, no Brasil, sem dúvida alguma, fazem parte de uma elite sócio-cultural.

A representação da instituição social na qual o artigo circula é, evidentemente, a da imprensa escrita, espaço de ampla comunicação pública, com todas as restrições que ela sofre, que vão desde as dos 
próprios proprietários dos jornal até os das empresas que aí anunciam. Mesmo que essa seção seja colocada pelo jornal como um espaço "democrático", aberto a diferentes posições, que podem não coincidir com as do próprio jornal, ele é um espaço também de coerção para o produtor do texto, visto que, ao se expor, sua imagem será avaliada por amplos setores da sociedade.

A representação que o produtor tem sobre seu objetivo pode ser vista como o de influenciar o pensamento de seus destinatários, isto é, o de construir ou de transformar (mudar, reforçar ou enfraquecer) a posição ou o comportamento dos destinatários em relação à questão proposta, por meio de uma posição sustentada por argumentos convincentes.

Assim, a análise da situação da ação de linguagem correspondente a esses textos, assim como o conhecimento que os professores envolvidos no projeto tem sobre as características dos alunos envolvidos (jovens trabalhadores da periferia de São Paulo) permitiu chegarmos à construção da primeira fase da seqüência didática.

Essa primeira fase envolveu a definição do projeto global da seqüência junto com os alunos e a sua colocação em uma situação de ação de linguagem bem definida, com uma instrução para uma primeira produção de um texto pertencente ao gênero a ser trabalhado, da seguinte forma:

"Produza um artigo de opinião, como representante de seu curso, dirigido a colegas de outros cursos que ainda não tenham uma posição firmada sobre a seguinte questão:

O panorama atual do mercado de trabalho brasileiro abre perspectivas favoráveis ou desfavoráveis à absorção de profissionais cada vez mais bem qualificados?

Redija o artigo de forma que ele possa ser publicado num possível jornal da Universidade."

A escolha desse tema vinha ao encontro dos argumentos dos professores, baseados no conhecimento que tinham de seus alunos, sobretudo no fato de que era trabalhadores, passando esse tema a ser o critério básico para a escolha dos textos a serem utilizados nos ateliers, assim como para a elaboração da instrução a ser dada aos alunos para sua produção inicial e final. 
Para a construção da segunda fase da sequiência didática, isto é, a série de ateliers, nos quais os alunos realizam diferentes atividades direcionadas para o projeto de apropriação das características fundamentais do gênero estudado, foram levadas em conta, inicialmente, duas necessidades decorrentes de nossos pressupostos teóricos. Em primeiro lugar, a necessidade de os alunos reconhecerem a influência das representações do produtor a respeito da situação de ação de linguagem sobre o texto e a necessidade de explicitá-las no momento da produção nos levou ao planejamento de um atelier em que, ao lado de informações teóricas, os alunos deveriam explicitar as suas representações para a produção inicial. Em segundo lugar, a necessidade da mobilização de conhecimentos sobre o tema tratado e de desenvolver a capacidade de identificação e seleção de informações de acordo com a situação de ação de linguagem em que se encontra levou-nos ao planejamento de ateliers que visavam, com a leitura de diferentes textos, levar os alunos a identificarem e a selecionarem informações que estivessem de acordo com suas representações a respeito de sua própria situação de ação de linguagem.

Para podermos planejar os ateliers seguintes, em que deveríamos trabalhar com as características dos diferentes níveis dos textos pertencentes ao gênero escolhido, e, sobretudo, as que considerávamos dever ser ensinadas/aprendidas - efetuamos uma análise mais detalhada de um artigo (de Fernando Bezerra Perspectivas favoráveis, FSP, 25/ 07,1998), que nos parecia ser um dos mais típicos para levantar essas características, e buscamos confirmá-las posteriormente com a leitura atenta de mais dez textos pertencentes a esse gênero.

A síntese dessa análise pode ser delineada como segue abaixo. Em relação à sua infraestrutura, isto é, em relação aos tipos de discurso e de seqüências, julgamos que alguns aspectos podem ser considerados como gerais e outros como específicos de cada texto:

a) os textos são, na sua maioria, heterogêneos, constituídos por segmentos de discurso misto, de discurso teórico e, em menor número, por segmentos de discurso interativo, o que aponta para uma dupla restrição a que está submetido o produtor: de um lado, a necessidade de tratar de temas atuais e de envolver o destinatário e, de outro lado, a necessidade de convencer, expondo suas posições (suas premissas, sobretudo) como verdadeiras e atemporais. 
Essa variação de tipo de discurso se evidencia pela presença de diferentes unidades lingüísticas presentes nos diferentes segmentos de texto categorizados em tipos de discurso diferentes:

- segmentos com ausência de qualquer tipo de dêitico (ausência de marcas da primeira e da segunda pessoa, de advérbios de tempo e lugar, e utilização do presente genérico, com efeito de uma verdade universal.

- segmentos com a utilização da primeira pessoa do plural, que na maior parte dos casos, não remete verdadeiramente ao produtor e ao destinatário, mas sim, configura-se como um nós genérico, que ora refere-se ao Brasil mesmo, ora aos brasileiros em geral, ora à elite política-econômica à qual o produtor pertence. $\mathrm{O}$ uso desse nós tem por efeito, de um lado, engajar os destinatários nas afirmações do produtor, mas, ao mesmo tempo, permite ocultar ou misturar responsabilidades sociais de cada agente social.

- em menor número, ainda podem aparecer segmentos de texto com dêiticos em geral, remetendo ao tempo e ao lugar da produção, com a utilização de advérbios de lugar e tempo e do presente com valor de simultaneidade e ainda com a presença da primeira pessoa do singular ou da segunda pessoa do plural.

Em relação à organização seqüencial, ela é predominantemente argumentativa, com a justaposição ou adição de várias seqüências argumentativas cujos argumentos vão fundamentando conclusões parciais que se tornam argumentos para a conclusão global, caracterizando o que se pode chamar de uma recursividade argumentativa, indicando que o produtor toma o objeto em discussão como sendo controverso e considera que há destinatários que não compartilham de suas opiniões. É normalmente, no final do texto, que aparece uma síntese das conclusões parciais defendidas no percurso do texto, assim como a reiteração - sob forma de paráfrase - da conclusão global. A conclusão da seqüência argumentativa global nem sempre corresponde a uma resposta à questão colocada pelo jornal, embora a ela se relacione ou dela seja derivada. Entretanto, essa resposta é, na maior parte das vezes, colocada explicitamente.

Cada argumento que sustenta as conclusões parciais ou a conclusão geral é habitualmente contido em um parágrafo, sendo a maior parte deles introduzidos por organizadores lógico-argumentativos ou por organizadores aditivos que relacionam argumentos do mesmo nível. Muitos desses argumentos são reforçados pela exposição de exemplos, 
fatos concretos, introduzidos também habitualmente por organizadores lógico-argumentativos. Nesses exemplos podem ser encontrados segmentos de discurso da ordem do NARRAR, organizados em seqüência de descrição de ações.

Localmente, também podem ser encontradas seqüências explicativas, que indicam que o produtor considera que objetos postos em discussão podem não ser de fácil compreensão para os destinatários. Assim, a operação de justificação das afirmações é muito constante e pode ser vista como a resposta do produtor a uma questão possível dos destinatários, como "por que você diz isso?", o que nos mostra o caráter extremamente dialógico desse gênero de texto. Uma outra faceta desse dialogismo se manifesta no fato de que o produtor freqüentemente prevê possíveis refutações dos destinatários ou possíveis conclusões contrárias às que ele quer conduzir, o que é marcado pela presença dos organizadores argumentativos do tipo de mas, entretanto, etc.

Em relação aos mecanismos de textualização, um dos aspectos mais marcantes é o fato de que a coesão nominal é feita predominantemente por meio de sintagmas nominais constituídos por pronomes demonstrativos anafóricos e nominalizações. Enfim, em relação à utilização de modalizadores, observa-se uma utilização marcante de modalizadores que indicam certeza tanto para reforçar os argumentos e os exemplos, quanto para enfatizar a conclusão central defendida pelo produtor. Em alguns textos, há ainda abundância de modalizadores deônticos. Tanto estes quanto aqueles constroem a imagem de um produtor que não negocia com o destinatário os pontos centrais de suas afirmações e que é detentor de um saber e de um raciocínio lógico que o torna apto a aconselhar, a interferir diretamente na atividade social por ele enfocada.

A análise que efetuamos dos elementos acima permitiu a elaboração de uma atividade de leitura analítica desenvolvida em dois ateliers, nos quais os alunos foram orientados a detectar essas características textuais, seus efeitos, e sua relação com a situação de ação de linguagem materializada nos textos, dando-se ênfase, sobretudo, à questão do dialogismo, da justificação e da negociação. 
Características gerais da sequência didática

Dessa forma, chegamos a um planejamento final da seqüência didática, que, até esse momento, nos parecia bastante satisfatória, contemplando uma visão verdadeiramente dialógica da linguagem. Resumidamente, ela é constituída de oito ateliers, da seguinte forma:

$1^{\text {o }}$ atelier: Apresentação do projeto global e de seus objetivos e produção inicial de artigo de opinião de jornal;

$2^{\circ}$ atelier: Identificação de elementos do contexto de produção do artigo de opinião de jornal e explicitação das próprias representações sobre o contexto da produção inicial;

$3^{\circ}$ atelier: Aumento de conhecimento sobre conteúdos necessários e distinção entre informações favoráveis ou desfavoráveis ao próprio posicionamento;

$4^{\circ}$ atelier: Seleção de informações de acordo com o contexto de produção;

$5^{\circ}$ atelier: Reconhecimento de algumas características do gênero, com a leitura dirigida de um artigo de opinião - o caráter dialógico, a recursividade da operação de justificação, os mecanismos enunciativos, os mecanismos de manutenção da coerência temática (conexão e coesão), o plano global do texto - todas elas sendo sempre relacionadas ao contexto de produção;

$6^{\circ}$ atelier: Retomada pelo conjunto da classe das principais questões do atelier anterior, direcionando-as para a produção individual;

$7^{\circ}$ atelier: Revisão da própria produção inicial, com base na ficha de controle;

$8^{\circ}$ atelier: Revisão da produção de um colega ,de acordo com os critérios das fichas de controle.

Finalmente, em consonância com o projeto global, elaboramos um modelo de ficha de controle do aluno (inspirada em Dolz \& Pasquier, 1993; Masseron, 1997b; Mas \& Turco, 1991), que, resumindo objetivos e atividades específicas de cada atelier, deveria lhes servir como orientação para a revisão da produção inicial e como ficha de avaliação para o professor, tanto para a primeira, quanto para a última produção do aluno. 


\section{Os conflitos na interação com os professores}

\section{Conflitos durante a elaboração da seqüência didática}

Terminada a primeira versão mais completa da sequiência didática, ela foi levada para discussão com os professores. Entretanto, as reações não foram exatamente as que estavam previstas. Sem haver propriamente uma crítica direta às atividades propostas, surgiram, no decorrer dessa discussão, comentários que nos pareciam estar indo em sentido totalmente contrário ao que pensávamos estar sendo sugerido, já que alguns dos professores demonstravam que o material didático elaborado, na verdade, não lhes apresentava atividades diferentes das que até então utilizavam. Para compreender melhor essa reação conseguimos levantar a hipótese de que deveria haver algo no próprio texto de planejamento da seqüência didática que estava produzindo o efeito de "déjà vu".

Assim, efetuamos uma análise mais detalhada desse texto e por meio dela detectamos uma contradição evidente entre o que havíamos desejado realizar e pensávamos ter realizado e o que nele realmente estava proposto. Em outros termos, pudemos detectar, no texto produzido por nós mesmos, como assessor docente, o que os formadores de professores observam, habitualmente, apenas nos discursos e práticas de professores em formação: a existência de "confusão entre teorias", a "dificuldade de transpor os conhecimentos teóricos para a prática".

Qual era, de fato, essa contradição? Ao analisarmos a primeira versão da sequiência apresentada aos professores e a versão posterior à sua discussão, pudemos apreendê-la mais claramente. Embora já tivéssemos utilizado, para a primeira, todo o arsenal teórico do interacionismo sócio-discursivo e efetuado análises coerentes com essa teoria, no processo de transposição dos conhecimentos, isto é, na formulação das atividades para os alunos, um acentuado privilégio foi dado à análise estrutural do texto, com o esquecimento, quase total, da influência dos elementos do contexto de produção sobre seus diferentes níveis.

Essa contradição parece-nos poder ser explicada e sua explicação pode ajudar-nos a esclarecer os problemas que os professores, por mais bem preparados que sejam, enfrentam em seu cotidiano. Na verdade, a experiência de produção de material didático que trazíamos era fortemente ligada à Lingüística Textual e, mesmo distante, no momento da 
transposição de novas conhecimentos científicos agora assumidos, a Lingüística Textual ganhou peso e influência consideráveis. De fato, se nas transposições didáticas anteriores, realizadas com base nesta teoria, nosso grupo já abordava a importância de se considerar, no processo de produção, os elementos constitutivos do contexto de produção, ao se passar para a abordagem dos mecanismos textuais propriamente ditos, esse contexto era totalmente esquecido, falha essa que se repetiu na nova experiência de elaboração de material didático.

\section{O conflito gerado pela primeira versão deste artigo}

Para finalizar esta seção, apresentamos a seguir o conflito gerado no trabalho de assessoria pela própria produção deste artigo, que, a nosso ver, constituiu-se em um momento dos mais importantes para a compreensão de todo o processo. Terminada a sua primeira versão, os princípios de ordem ética que têm guiado nosso trabalho junto aos professores, levaram-nos a apresentá-lo a eles, para que avaliassem a justeza e a veracidade de nossas descrições e considerações. Uma das críticas mais acentuadas foi a de que não expúnhamos, claramente, o quanto e como as injunções institucionais, principalmente o tempo previsto para a implantação do projeto-piloto, havia determinado os papéis assumidos, de fato, pela assessora e pelos outros participantes do processo. Segundo um dos professores, a imagem que deles era construída no artigo era a de meros aplicadores da sequiência elaborada, o que lhes parecia ser uma minimização de seu trabalho. Se, como admitiam, de fato, eles haviam tido um papel menos ativo na elaboração da sequiência, as razões que haviam levado a isso não eram apontadas de forma suficiente.

Em primeiro lugar, segundo suas palavras, já trazíamos, bem dominado, um modelo teórico e a sua possível aplicação prática que não eram compartilhados pelos professores, formados que eram em outros paradigmas. A pressão do fator tempo não teria permitido que esse modelo teórico pudesse ser realmente compartilhado, condição indispensável para uma verdadeira construção conjunta da seqüência, teoricamente ideal. Assim, ainda segundo sua interpretação, pressionados por esse fator tempo e tendo uma visão de conjunto previamente elaborada, as diferentes atividades acabaram por ser efetivamente delineadas pela assessora, praticamente sozinha, e levadas aos professores apenas 
para uma discussão conjunta. Assim, o papel real dado a eles, não por sua opção, foi apenas o de efetuarem sugestões e reelaborações das atividades sugeridas.

O que ressalta dessas observações é que elas são o exemplo mais concreto de como não dominamos os efeitos de sentido de nosso discurso. Na verdade, de forma consciente, o objetivo do artigo, na versão anterior que foi criticada pelos professores, era exatamente o contrário, era o de acentuar o caráter de construção conjunta da elaboração da sequiência didática.

Além disso, também não havia, na versão deste artigo discutida com os professores, uma explicitação clara sobre o que se compreendia como construção conjunta e sobre o que havia sido realmente construído. Mais uma vez, é no discurso dos professores que encontramos esclarecimento sobre esta última questão. Se, de fato, a seqüência em si mesma não foi construída conjuntamente, em sentido estrito; segundo eles, o ganho coletivo, assim mesmo, foi inestimável, na medida em que, em um tempo exíguo, inúmeras representações de todos os participantes, inclusive as nossas, dos assessores, referentes ao ensino-aprendizagem de produção de textos sofreram transformações significativas, construindo-se um conjunto mínimo de conhecimentos compartilhados pelo grupo.

Nesse sentido, parecia-lhes que a própria discussão do artigo se constituiu como um passo importante para a reconstrução de representações sobre o trabalho realizado, gerando-se esclarecimentos sobre ele, sobre como nos vemos, sobre os papéis que realmente aí assumimos. Portanto, a construção conjunta real não se teria dado no nível da elaboração da seqüência propriamente dita, mas em um nível superior e mais importante.

Finalmente, apontaram a necessidade de serem mostradas, no artigo, as perspectivas que se abrem para o trabalho desenvolvido até aqui. Dessa forma, podemos afirmar que todos nós (e aqui esse nós inclui, de fato, assessores e professores) esperamos que, atingido esse patamar de conhecimentos compartilhados, os assessores, pouco a pouco, possam ir saindo de cena, ou melhor, assumindo um papel de coordenadores do processo e não de seus agentes centrais. Na medida em que, após a execução do projeto-piloto e com a perspectiva da implantação da nova rede curricular, surge a necessidade de elaboração de inúmeras seqüências didáticas sobre gêneros específicos para diferentes cur- 
sos, surge também a necessidade da criação de subgrupos de professores para essa elaboração, os quais, com um corpo de conhecimentos e representações compartilhadas, poderão assumir, de fato, o papel de sujeitos agentes e, portanto, de responsáveis diretamente por ela.

\section{Conclusões}

As conclusões que elencamos a seguir se referem a diferentes aspectos do trabalho desenvolvido. Em relação aos aspectos teóricos envolvidos na transposição didática, ficou evidenciado que as atividades desenvolvidas para se efetuar uma transposição didática pertinente podem levar-nos a uma compreensão mais elaborada da própria teoria previamente escolhida e que há necessidade de considerarmos outras teorias, elaboradas principalmente pelos "experts" no gênero em questão. Corroboramos ainda aqui a necessidade de serem efetuadas análises completas sobre os diferentes níveis da atividade educacional na qual os trabalhos de assessoria e de transposição didática se inserem, a fim de que sejam adequadas e pertinentes a essa atividade educacional, e não de forma abstrata e idealizada. Para isso, a análise do discurso de diferentes documentos oriundos de diferentes instâncias educacionais assumem um papel fundamental.

Foi justamente isso que nos permitiu verificar que as necessidades e as exigências institucionais, dos níveis mais altos aos mais baixos acabam por gerar restrições ao trabalho a ser desenvolvido, que consideramos ser inevitáveis nos trabalhos realizados por demanda institucional. Entretanto, é necessário que compreendamos essas restrições, que nos adaptemos a elas, mesmo se isso nos obrigue até mesmo a agir contra nossas concepções sobre um trabalho de assessoria e de transposição didática idealmente perfeita do ponto de vista metodológico ou teórico. Em suma, essas restrições parecem-nos não impedir uma ação de intervenção educacional que, mesmo com elas, tenha resultados positivos.

No nosso caso específico, por exemplo, ficou evidente que não tivemos tempo de construir, previamente, um modelo didático perfeito do gênero estudado, o que seria teoricamente indispensável. Entretanto, o grau de domínio e dos conhecimentos teóricos que os participantes do trabalho tinham sobre ele permitiu, assim mesmo, a construção 
paulatina desse modelo durante o processo mesmo de elaboração da seqüência didática.

Quanto ao(s) procedimento(s) utilizado(s) para a elaboração dessa seqüência, confirmamos nossa hipótese de que há necessidade de realizála conjuntamente, no mínimo, submetendo-a à discussão, à crítica e às sugestões dos professores envolvidos. Mesmo reconhecendo que, no caso relatado, não houve uma verdadeira construção conjunta em sentido estrito, julgamos que é evidente que a sequiência didática produzida jamais seria o que é, se não tivesse sido discutida com os professores, reestruturada por seus questionamentos e modificada por suas sugestões.

Em relação às consequiências sobre a aprendizagem da produção de textos, a elaboração da sequiência didática apontou-nos que, de acordo com sua formulação, mais que levar o estudante à maestria de um determinado gênero, ela pode conduzi-lo à percepção e à apropriação de certos procedimentos (ou de certas operações de linguagem), indispensáveis à produção de qualquer gênero, o que pode contribuir para desenvolver sua capacidade de, sozinho, apreender as dimensões constitutivas de um texto que devem ser observadas e analisadas quando se defrontar diante do desafio de produzir um texto pertecente a um gênero que não lhe foi formalmente ensinado.

Finalmente, quanto ao trabalho de assessoria docente (ou de formação contínua de professores), acreditamos que a experiência relatada assinala o valor e a preocupação contínua que se deve ter com uma verdadeira escuta do outro, mesmo daquele que, em um determinado contexto, pode ser considerado aprioristicamente como sendo o par menos desenvolvido em relação a um determinado conjunto de conhecimentos e procedimentos. O que se evidenciou é que essa 'escuta' pode contribuir de forma decisiva para profundas transformações naquele que é considerado como o par mais desenvolvido. Entretanto, essa escuta só será verdadeiramente eficaz, na medida em que assessores e formadores de professores se voltarem para uma análise crítica de seu próprio discurso e perceberem que as contradições entre teorias e práticas, entre o dito e a prática real não se encontram apenas em um dos pólos da interação, mas que é constitutiva de todos nós.

Ainda em relação a esse trabalho de assessoria docente, consideramos que ele bem exemplifica um processo de desenvolvimento, numa perspectiva vigotskiana. Partindo de uma atividade social de constru- 
ção de objetos de conhecimentos, com a própria elaboração da seqüência didática servindo de ferramenta privilegiada, agentes que já tinham maior domínio sobre essa tarefa mostraram a forma de realizá-la para outros agentes que, teoricamente, tinham um menor domínio sobre ela. Assim, parece-nos terem sido criadas condições favoráveis para que esses objetos de conhecimentos fossem construídos de tal forma que estes últimos agentes possam, a seguir, realizar essa tarefa e outras semelhantes a ela, dessa vez sozinhos, em direção a um grau crescente de consciência e de autonomia da própria ação.

Nesse sentido, a concepção de sistema triádico, que foi por nós emprestada da concepção de sistema didático, parece, de fato, pode ser estendida à assessoria docente (ou à formação de professores); que deve ser considerada como uma necessidade de todos os níveis de ensino, aí incluído o universitário, e compreendida como um processo de formação de todos os participantes nela engajados, aí incluídos os próprios assessores (ou formadores).

Em suma, o trabalho desenvolvido mostra ter atingido resultados positivos até as fases aqui relatadas, seja em relação à formação dos professores, seja em relação à transposição dos conhecimentos científicos para conhecimentos a serem ensinados. Resta-nos agora verificar os resultados concretos da aplicação da sequiência didática, com a avaliação que professores e estudantes dela fizeram e com a análise das produções dos estudantes e das capacidades que foram efetivamente desenvolvidas, o que nos permitirá chegar a uma avaliação mais ampla de todo o trabalho desenvolvido.

\section{REFERÊNCIAS BibLIOGRÁFICAS}

Bakhtin, M. (1953). Estética da criação verbal., Livraria Martins Fontes, 1992. (Col. Ensino superior): São Paulo

BräKling, K.; R. Soligo \& T. Weiz (1998). Parâmetros curriculares nacionais para língua portuguesa $-3^{o}$ e $4^{o}$ ciclos. Brasília: MEC. Bronckart, J.-P. (1993). Action theory and the analysis of action ineducation. European Association for Research on Learning and Instruction. $5^{\text {th }}$ European Conference, Aix-en-Provence. (mimeo). (1997). Activité Langagière, Textes et Discours - pour un Interactionisme Socio-discursif. Lausanne: Delachaux et Niestlé. 
\& B. Schneuwly. (1991). La didactique du français langue maternelle: l'émergence d'une utopie indispensable. Education et Recherche, 1: 8-25.

de Pietro, J.-F.; S. Erard \& M. Kaneman-Pougatch (1997). Un modèle didactique du "débat": de l'objet social à la pratique scolaire. Enjeux: 39:40.

Dolz, J. \& Pasquier, A. (1993). Séquence didactique 6P. “Argumenter...pour convaincre” - initiation aux textes argumentatifs. Genebra: Serviço de Francês.

\& B. Schneuwly (1998). Pour un enseignement de l'oral Initiation aux genres formels à l'école. Paris: ESF (Collection Didactique du Français).

. \& B. Schneuwly (no prelo).A la recherche de moyens d'enseignement pour l'expression écrite et orale. In: S. Plane, (ed.), Enseigner le Français avec ou sans Manuels? (mimeo).

Mas, M. \& G. Turco (1991). Des typologies de textes à l'élaboration d'outils pour la formation des maître et d'outils pour la classe. Textes, DiscoursTtypes et Genres. Etudes de Linguistique Apliquée, juillet-septembre: 89-99.

Masseron, C. (1996) Présentation. Pratiques, 92: 3-4.

(1997).Pour une didactique de l'argumentation (écrite): problèmes, objets e propositions (II). Pratiques 96: 35-61.

PAsquier, G. \& J. Dolz (1996) Un decálogo para enseñar a escribir. Cultura y Educación, 2: 31-41.

Schneuwly, B. (1991) Diversification et progression en DFLM: l'apport des typologies. Textes, discours types et genres. Etudes de Linguistique Apliquée, juillet-septembre: 131-141.

(1994) Genres et types de discours: considérations psychologiques et ontogénétiques. In: Y. REUTER (ed.), Actes du Colloque de L'université Charles-De-Gaulle III. Les interactions lecture-écriture. Neuchâtel: Peter Lang: 155-173.

Rangel, E. de O.; A. R. Machado; M.C.C. Magalhães \& A. L. M. Garcia (1998). Projeto Cultura da Escrita: Atividades de Leitura e Escrita na Universidade. São Paulo: Instituto de Assessoria e Pesquisa em Linguagem. (mimeo).

(Recebido em setembro de 1998; Aceito em junho de 1999) 